\title{
A New Species of Chaunus from Central Brazil (Anura; Bufonidae)
}

\author{
Reuber A. Brandão, ${ }^{1,2}$ Natan M. Maciel, ${ }^{3}$ and Antonio Sebben ${ }^{4}$ \\ ${ }^{1}$ Departamento de Engenharia Florestal (EFL), Universidade de Brasília (UnB), Campus Darcy Ribeiro, 70910-900, \\ Brasília, Distrito Federal, Brazil \\ ${ }^{3}$ Laboratório de Toxinologia (LTx), Departamento de Ciências Fisiológicas (CFS), Instituto de Ciências Biológicas (IB), \\ Universidade de Brasília (UnB), ICC-Sul, Módulo 5, Campus Darcy Ribeiro, 70910-900, Brasília, Distrito Federal, Brazil \\ ${ }^{4}$ Laboratório de Anatomia Comparativa de Vertebrados, Departamento de Ciências Fisiológicas (CFS), Instituto de Ciências \\ Biológicas (IB), Universidade de Brasília (UnB), ICC-Sul, Módulo 5, Campus Darcy Ribeiro, 70910-900, Brasília, \\ Distrito Federal, Brazil
}

\begin{abstract}
Aвstract.-A new species of Chaunus, apparently related to Chaunus arenarum, Chaunus rubescens, and Chaunus achavali is described. The new species occupies Cerrado habitats in southwestern Piauí and Bahia states and in northwestern Minas Gerais state, Brazil. The species is characterized by anterior interruption of the supraocular crest; weakly developed cranial crests; short and robust limbs; several pointed spiculae on dorsum, head, and limbs; male coloration; small to medium size; and by the short and narrow head.
\end{abstract}

Until recently, the genus Bufo was interpreted as a large paraphyletic assemblage (Graybeal and Cannatella, 1995; Pramuk, 2006), composed of more than 250 species distributed through all continents, except for Arctic, Antarctic, Madagascar, New Guinea, Australia, and oceanic islands. Some species, such as Bufo marinus, were introduced in many places of the world (D. R. Frost, Amphibian Species of the World, version 3.0, available online at http://research. amnh.org/herpetoloty/amphibian/index.html, 2004; Slade and Moritz, 1998).

The large number of species and the complex evolutionary history of the South American species of Bufo led to several attempts to classify and group them (Gallardo, 1962; Tihen, 1962; Cei, 1972, 1980; Martin, 1972; Duellman and Schulte, 1992; Frost et al., 2006; Pramuk, 2006).

Based on osteological features, Tihen (1962) proposed the so-called South American section, consisting of Bufo arenarum; Bufo blombergi; Bufo chilensis (= Bufo arunco); Bufo crucifer; Bufo ictericus; Bufo m. marinus (= Bufo marinus); Bufo m. horribilis (= Bufo marinus); and Bufo paracnemis (= Bufo schneideri).

Gallardo (1962) was the first author to define the $B$. marinus group to refer to a subgroup of Neotropical Bufo species having the parotoid gland behind the eye, passing over the eardrum, and by the skin that covers these glands, which has a different aspect from the rest of the body, because of the large pores. Gallardo (1962) included in his B. marinus group almost all South American Bufo: Bufo arenarum; Bufo blombergi; Bufo caeruleostictus; Bufo ceratophrys; Bufo crucifer; $B$.

\footnotetext{
${ }^{2}$ Corresponding Author. E-mail: reuberbrandao@ yahoo.com.br
}

Bufo dapsilis; Bufo fissipes; Bufo glaberrimus; Bufo guttatus; Bufo haematiticus; Bufo ictericus; Bufo inca; Bufo intermedius; Bufo leptocelis (misspelling of Bufo leptoscelis (= B. veraguensis)); Bufo manicorensis (= Bufo granulosus); Bufo marinus; Bufo ocellatus; Bufo ockendeni (= Bufo veraguensis); Bufo paracnemis (= Bufo schneideri); Bufo pithecodactylus (= Bufo marinus); Bufo poeppigii; Bufo quechua; Bufo rostratus (= Rhamphophryne rostrata); Bufo rubropunctatus; Bufo rufus (= Bufo rubescens); Bufo schneideri (considered by Gallardo 1962 as a possible synonym of Bufo paracnemis); Bufo spinulosus; and Bufo typhonius (= Bufo margaritifer). Gallardo (1962) suggested that Bufo schneideri was a senior synonym of Bufo paracnemis. However, in the original description, Bufo schneideri is considered most closely related to $B$. sternosignatus, a species of the former Bufo valliceps group (D. R. Frost, Amphibian Species of the World, version 3.0, available online at http://research.amnh.org/herpetoloty/ amphibian/index.html, 2004). The holotype of Bufo schneideri is a small female (SVL= $69.7 \mathrm{~mm}$ ) with evident tibial glands, confirming Gallardo's (1962) interpretation (pers. obs.).

Martin (1972) defined the B. marinus species group based on the following morphological characters: skull short and broad; broad frontoparietals with lateral edges forming prominent supraorbital crests that extend anteriorly onto the nasals and bifurcate to form prominent canthal and preorbital crests; supraorbital crests joined in a smooth arc by the postorbital crests, which in turn are joined laterally by the tympanic and supratympanic crests; frontoparietal-nasal nearly transverse; dermal roofing bones heavily ornamented; absence of distinct parietal crests, but the area they usually occupy is elevated by parallel ridges of bones; post- 
orbital shelf extensive and trapezoidal in shape; otic plate of the squamosal large; frontoparietals fused to the prootics; occipital canal closed; braincase moderately depressed to slightly elevated; rami of the squamosal of average or less than average length; medial rami of the pterygoids overlap the wings of the parasphenoid over half their length; suprapterygoid fenestra nearly occluded by flanges from the squamosal and the medial arm of the pterygoid. Martin (1972) included B. schneideri, B. ictericus, $B$. marinus, and $B$. arenarum in the group.

Cei (1972) recognized two major radiations of South American Bufo, delimited by the Andean Cordillera. The Broad-Skulled Toads are represented by the B. marinus, B. granulosus, $B$. margaritifer, and B. guttatus groups and occur east of the Andes. The Narrow-Skulled Toads are represented by the B. spinulosus group, found on the western versant of the Andes. Cei (1972) reviewed the B. marinus group and included B. marinus, B. poeppigii, B. arenarum, $B$. rubescens, B. ictericus, and B. schneideri. Cei (1980) split the B. marinus group, allocating $B$. arenarum and $B$. rubescens to a separate group, based mostly on medium to small size, weak development of cranial crests, and tongue shape.

Lavilla (1992) noted that B. rufus is a name already occupied by $B$. rufus, a junior synonym of Bufo terrestris. Faivovich and Carrizo (1997) removed Bufo missionum from the synonymy of B. rufus where it had been placed by Gallardo (1961). According to D. R. Frost (Amphibian Species of the World, version 3.0, available online at http:/ / research.amnh.org/herpetoloty / amphibian/index.html, 2004) B. rubescens is the valid and current name for the species. This species is found in the states of Minas Gerais and Goiás, Brazil (Cochran, 1955; D. R. Frost, Amphibian Species of the World, version 3.0, available online at http://research.amnh.org/ herpetoloty/amphibian/index.html, 2004), and it is common in Central Brazil, especially in the highlands of Goiás and Distrito Federal (Eterovick and Sazima, 1999; Brandão and Araujo, 2002; D. R. Frost, Amphibian Species of the World, version 3.0, available online at http:/ / research.amnh.org/ herpetoloty/amphibian/index.html, 2004).

Duellman and Schulte (1992) redefined the $B$. marinus group to include $B$. arenarum, $B$. ictericus, B. marinus, B. poeppigii, B. rubescens, and $B$. schneideri. These species share broad frontoparietals fused with prootics; completely roofed occipital canal; pronounced exostosing of dermal roofing bones; presence of all cranial crests, elevated, keratinized or not; presence of large and small tubercles on the dorsal skin; absence of a lateral row of enlarged tubercles; parotoid glands large, ovoid or elongate; tympanum distinct; snout round in dorsal view, truncate in profile; and first finger longer than second. Later, Bufo jimi and Bufo achavali were described and included in the group (Stevaux, 2002; Maneyro et al., 2004).

Pramuk (2006) provided morphological synapomorphies to diagnose the recognized species groups of South American Bufo but did not propose any taxonomic changes. According to her, the so-called B. marinus group presents a unique and unreversed synapomorphy, a jagged or "scalloped" suture between the articulation of the medial ramus of the pterygoid and the parasphenoid alae.

Frost et al. (2006) suggested that the genus Chaunus must be revalidated for a clade supported by molecular characters, grouping 43 Neotropical Bufo species. Despite recent changes in Bufonidae taxonomy (Frost et al., 2006), the composition of the phenetic groups remains unchanged.

The Chaunus marinus group is composed so far by eight species: Chaunus achavali, Chaunus arenarum, Chaunus ictericus, Chaunus jimi, Chaunus marinus, Chaunus poeppigii, Chaunus rubescens, and Chaunus schneideri. All species of $C$. marinus species group occurs in Brazil, except C. poeppigii (D. R. Frost, Amphibian Species of the World, version 4 available online at http://research.amnh.org/ herpetology/amphibia/index.php, 2006; M. DiBernardo, A. Kwet, and R. Maneyro, pers. comm.). Herein we describe a new species of the $C$. marinus group from the Brazilian Cerrado morphologically similar to $C$. arenarum, C. rubescens, and Chaunus achavali.

\section{Materials and Methods}

Specimens used for description and comparisons are deposited in Coleção Herpetológica da Universidade de Brasília (CHUNB), Museu Nacional (MNRJ), Adolpho Lutz collection (AL, housed at MNRJ), Museu de Ciências e Tecnologia da Pontifícia Universidade Católica do Rio Grande do Sul (MCP), Naturhistorisches Museum (NHMB), and Museu de Zoologia da Universidade de São Paulo (MZUSP). Measurements were taken using a digital caliper (to nearest $0.1 \mathrm{~mm}$ ). For measurements, we follow Heyer et al. (1990) and Maneyro and Arrieta (2000). We took the following 20 measurements: snout-vent length (SVL), head length (HEL), head height $(\mathrm{HH})$, head width $(\mathrm{HW})$, maximum length of parotoid gland (PGL), maximum width of parotoid gland (PGW), tympanum diameter (TD), eye diameter (ED), eye to nostril distance (END), interocular distance (IOC), interorbital distance (IOD), internostril distance (IND), snout to nostril distance (SND), hand length (HAL), forearm length (FAR), upper arm length (UAR), tibia length (TIL), thigh length 
(TL), tarsus length (TL), and foot length (FL). The webbing formulae follow Heyer et al. (1990). Sex was determined by the observation of secondary sexual characters, such as the presence of keratinous pointed spicules on dorsum, keratinization of fingers and arms, and vocal sacs. We confirmed these features as characteristics of mature males by examination of the gonads of male and female specimens.

\section{Results}

Chaunus veredas sp. nov.

Figures 1-3

Holotype.-Coleção Herpetológica da Universidade de Brasília (CHUNB 40282), adult male collected at Trijunção Farm (currently Parque Nacional Grande Sertão Veredas), Cocos Municipality, Bahia State, Brazil $\left(14^{\circ} 49^{\prime} \mathrm{S} ; 45^{\circ} 58^{\prime} \mathrm{W}\right)$ in October 2000, by R. A. Brandão, G. J. Zerbini, M. A. Bagno, and J. B. Pereira.

Paratypes.-CHUNB 37437-37438 (two adult females), collected along with the holotype; CHUNB 34106-34109, 34112-34114 (two adult males, two adult females, and three juveniles), collected at Serra das Araras State Park, Serra da Araras Municipality, Minas Gerais State; CHUNB 38652-38654 (three adult males) collected at Trijunção Farm, Cocos Municipality, Bahia State; MZUSP 128285A-128293A (four adult males, four adult females, and a juvenile) collected at Grande Sertão Veredas National Park, Chapada Gaúcha Municipality, Minas Gerais State; CHUNB (43327-43333; four adult females and three adult males) collected at Buritizeiro Municipality, Minas Gerais State; MNRJ 1387 (an adult male) collected at Pirapora Municipality, Minas Gerais State; MNRJ 3901439017 (an adult male and three adult females) collected at Pirapora Municipality; MNRJ 39035 (an adult male) collected at Corrente Farm, Várzea da Palma Municipality, Minas Gerais State; MNRJ (39051-39052; two adult males) collected at Pirapora Municipality, Minas Gerais State; MNRJ (39050; an adult male) collected at Estação Ecológica Uruçuí-Una, Uruçuí-Una Municipality, Piauí State.

Diagnosis and comparisons with other species.The new species belongs to the $C$. marinus species group mostly by the size, rough skin, parotoid gland shape, distinct tympanum, and first finger longer than second (Duellman and Schulte, 1992). Chaunus veredas has the following unique combination of characters within the $C$. marinus group: anterior portion of the supraocular crest bearing a distinct interruption (Fig. 1A); supranasal crests slightly developed; cranial crests poorly developed; high density of keratinous pointed spicules in dorsal glands;
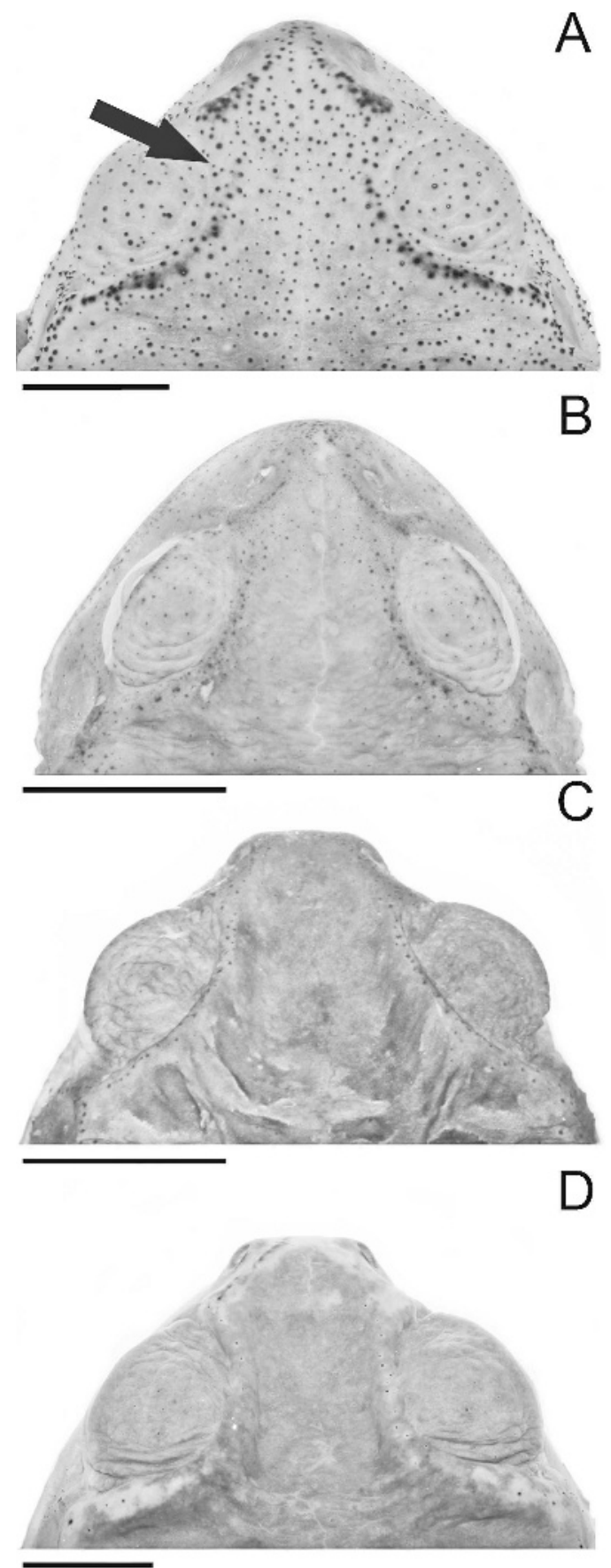

FIG. 1. Dorsal view of the head of Chaunus veredas (A), showing the anterior interruption of the supraocular crest; Chaunus rubescens (B); Chaunus achavali (C); and Chaunus arenarum (D). Scale bars: $10 \mathrm{~mm}$. Photos by Natan Maciel. 


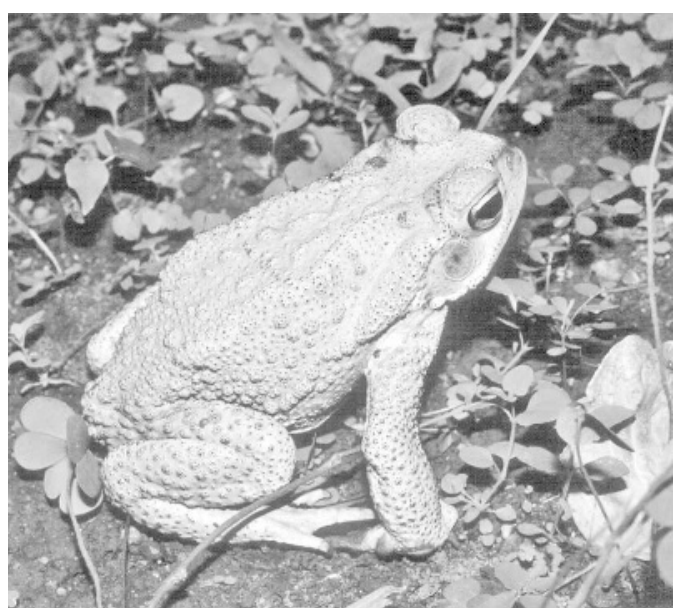

FIG. 2. Adult male of Chaunus veredas from Cocos, Bahia State, Brazil. Photo by Natan Maciel.

limbs short and robust; fingers short and robust; males commonly have a yellow dorsum and venter immaculate white; females larger, robust, with dorsum marmoreal brownish and greenbluish, resembling coloration of $C$. arenarum; very short head, head wider than long; small to medium size (males $87.0-110.7 \mathrm{~mm}$; females $82.8-117.8 \mathrm{~mm}$ ), foot webbing formula I 1-2 II 2-3 III 3-3 IV 3-2 V; parotoid gland elongated and narrow; absence of tibial gland. The new species is most similar to C. rubescens, C. arenarum, and $C$. achavali based on the weak development of cranial crests, shape of the parotoid gland, and relatively short fingers and toes. The new species can be distinguished from $C$. rubescens by anterior interruption of the supraocular cranial crest (complete in C. rubescens) (Fig. 1B); short and rounded parotoid gland (long and narrow in C. rubescens); distinct glandular ridges, extending from the posterior end of the parotoid gland, to the groin (absent in C. rubescens); larger size (males $87-110.7 \mathrm{~mm}, \mathrm{~N}$ $=20$, in C. veredas, males $74.3-103.4 \mathrm{~mm}, N=$ 14, in C. rubescens); dorsal yellow coloration in males (males tan, brown or gray, but never yellow in C. rubescens); foot webbing formula (I 1-1 II 2-1 III 2-1/2 IV $1 / 2-2 \mathrm{~V}$ in C. rubescens); head wider than long; rounded snout in lateral view (obtuse in C. rubescens); presence of keratinous spiculae on body glands. From $C$. achavali, the new species can be distinguished by dorsal yellow male coloration (tan or graybrown in C. achavali); anterior interruption of the supraocular crest (complete in C. achavali; Fig. 1C); pointed spiculae on body glands; rough skin (smooth in C. achavali); foot webbing formula; and pale yellow parotoid glands (reddish-brown in C. achavali). From C. arenarum, the new species can be distinguished by
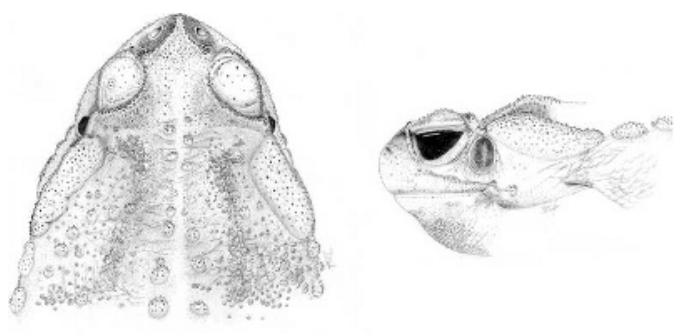

A

B
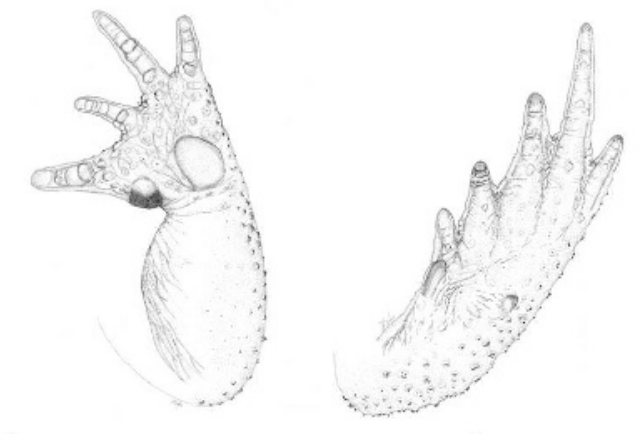

C

D

FIG. 3. Chaunus veredas, CHUNB 40282 (holotype) adult male, (A) dorsal view of head, (B) lateral view of head, (C) palmar view, (D) plantar view. Scale: $10 \mathrm{~mm}$. Drawings by Daniel Sifuentes.

the anterior interruption of the supraocular crest (complete in C. arenarum; Fig. 1D); larger size (males $70.2-100.8, N=16$, in C. arenarum); rough skin (smooth in C. arenarum); foot webbing formula (I 2-2 II 3-1 III 2-1/2 IV $1 \frac{12-}{2}$ $2 \mathrm{~V}$ in $\mathrm{C}$. arenarum); rounded snout in lateral view (truncated in C. arenarum); abundance of keratinous pointed spicules in all dorsal glands; yellow dorsal male coloration (males marbled with light blue and ochre in C. arenarum); and a narrow and long tongue (short and rounded in C. arenarum). From C. ictericus, C. schneideri, C. marinus, and $C$. jimi by its anterior interruption of the supraocular cranial crest, weak development of cranial crests, smaller size, shorter and robust limbs, shape of parotoid gland, and lack of tibial glands.

Description of the holotype.-General aspect robust (Fig. 2). Head wider than long; SVL approximately $3 \times$ the head width; snout rounded in dorsal and in lateral views (Fig. 3A and $3 \mathrm{~B}$ ); loreal region smooth; large nostrils, with dorsally elliptic opening; interorbital distance approximately $2 \times$ the eye diameter; tympanum developed, oval; eye diameter about $1.25 \times$ the tympanum diameter; cranial crests present, weakly developed; pretympanic and rostral crests slightly developed; supraocular crest indistinct anteriorly but evident from the medial part of the ocular globe until its 
posterior end; supranasal crest evident, slightly developed; postocular crest developed, short, in contact with the parotoid gland; cranial crests keratinized, more pigmented in the thicker areas; dorsum of the head plane, with small rounded spiculae; large eyelid, with or without small keratinous spicules (Fig. 1A). Parotoid gland evident, ellipsoid, with keratinous spicules; parotoid length about $3 \times$ in its width. Tongue wider than long, pear shaped, smooth, without folds, free in its posterior end; posterior tongue margin broad and rounded, anterior margin narrow, attached to jaw; vomerine teeth absent; vocal sac under the tongue; vocal sac slits rounded, located next to the mandible comissure; choanae elliptic. Fingers developed (Fig. 3C); forearm and arm robust and short; relative finger length II $<$ IV $<$ I $<$ III; fingers without webbing, but with slightly developed fringes; tips of fingers keratinized and dark in dorsal view; subarticular tubercles at the base of all fingers; subarticular tubercle present between phalanges II and III of finger III; outer palmar tubercle large and rounded; inner palmar tubercle at base of finger I, rounded, with posterior edge pigmented and keratinized. Nuptial pads evident, dorsally visible on fingers I and II. Snout-vent length about $2.4 \times$ the thigh length; toe-tips keratinized and dark, relative length of toes I $<$ II $<$ V $<$ III $<$ IV; small subarticular tubercles proximally on toes; subarticular tubercles between phalanges II and III on toes III, IV and V. Foot web present, weakly developed; foot webbing formula I 1-2 II 2-3 III 3-3 IV 3-2 V; outer metatarsal tubercle small, rounded; inner metatarsal tubercle elongated, weakly keratinized. Metatarsal fold present, from the tip of toe I to the base of the shank; plantar surface with small callosities, weakly developed and conical. Dorsal skin rough; dorsum covered by rounded glands, of similar size; all glands with black and pointed keratinized spiculae; spiculae number changes with gland size; glands are smaller and less dense in the anterior and posterior limbs. An evident dorsolateral glandular ridge extends from the posterior edge of the parotoid gland to the groin, separating the dorsal and ventral body surfaces; ventral surface smooth.

Measurements of the holotype (in millimeters).SVL 106.0; HEL 29.7; HH 23.8; HW 435.9; PGL 23.4; PGW 9.7; TD 6.7; ED 11.6; END 4.7; IOC 13.4; IOD 11.3; IND 7.4; FN/DFN 3.3; HAL 23.7; FAR 24.0; UAR 15.7; TIL 37.4; TL 44.7; TL 21.6; and FL 40.9.

Variation.-The individuals showed little variation in the head ridges and overall morphology, but males are more elongated than females. Some males have dorsum light gray, similar to the substratum color. Keratinous spiculae are more developed in males than in females. Species measurements are provided in Table 1.

Coloration.-Sexual dimorphism well marked in coloration. In life, most males show a bright yellow dorsum, with dark points corresponding to the keratinous spiculae and a white immaculate venter. Females show a complex pattern of greenish and ochre on the dorsum, and a white immaculate venter. Newly metamorphosed individuals show large black and white spots in belly and chest, and the vent is orange. Preserved males become buff, with white venters; females with grayish and pale brown dorsum. The spiculae remain dark or brown.

Etymology.- "Vereda" is a typical kind of cerrado vegetation, characterized by the occurrence of buriti palms (Mauritia flexuosa), that develop along small rivers and water courses. The name is derivative from the old Portuguese language and means pathway, in contrast to the "cerrado" that means dense or closed, and is used as a noun in apposition. The region of the type locality of Chaunus veredas was the setting of "Grande Sertão: Veredas," by João Guimarães Rosa, one of the greatest Brazilian writers. This novel was the inspiration for the name of the Grande Sertão Veredas National Park, one of the most important remnants of Cerrado, with about 231,000 ha. The specific epithet is in homage to Guimarães Rosa, to Grande Sertão Veredas National Park, and to the vereda vegetation.

Distribution.-Chaunus veredas was recorded in sandy ground chapadas (plane highlands) in the southwestern States of Piauí (Uruçuí-Una Ecological Station) and Bahia (Cocos Municipality) and northeastern Minas Gerais (Formoso, Serra das Araras, Chapada Gaúcha, Pirapora, Várzea da Palma and Buritizeiro municipalities; Fig. 4).

Natural history notes.-Although we carried out continuing studies at Trijunção Farm region since 1998, C. veredas was observed only a few times, always at the beginning of the rainy season (October/November). Individuals were found in open areas (cerrado, campo cerrado, veredas, and campo sujo). We never observed reproductive activity or found tadpoles. However, in December we found toadlets close to wet areas, but no adults were observed. Leptodactylus troglodytes, Pleurodema diplolistris, and Physalaemus centralis are found in the same habitats as $C$. veredas.

\section{DisCUSSION}

Chaunus veredas is endemic to the Brazilian Cerrado biome, and it is easily distinguishable from other species in the Chaunus marinus group. 
TABle 1. Measurements (in millimeters) for the type series of Chaunus veredas. Mean followed by standard deviation (SD) and ranges.

\begin{tabular}{|c|c|c|c|c|}
\hline \multirow[b]{2}{*}{ Variables } & \multicolumn{2}{|c|}{ Males $(N=20)$} & \multicolumn{2}{|c|}{ Females $(N=14)$} \\
\hline & Mean $( \pm S D)$ & Ranges & Mean $( \pm S D)$ & Ranges \\
\hline Snout-vent length & $98.3( \pm 7.1)$ & $87.0-110.7$ & $101.9( \pm 9.7)$ & $82.8-117.8$ \\
\hline Head length & $27.5( \pm 1.5)$ & $25.0-29.7$ & $28.0( \pm 2.5)$ & $21.0-31.1$ \\
\hline Head height & $19.5( \pm 3.1)$ & $14.2-24.2$ & $19.7( \pm 2.6)$ & $14.5-24.8$ \\
\hline Head width & $33.9( \pm 1.9)$ & $30.2-36.7$ & $34.2( \pm 2.5)$ & $29.0-37.2$ \\
\hline Max. length of parotoid gland & $22.2( \pm 1.9)$ & $18.8-26.4$ & $23.5( \pm 2.2)$ & $19.3-26.9$ \\
\hline Max. width of parotoid gland & $10.3( \pm 1.6)$ & $7.9-14.7$ & $11.0( \pm 1.8)$ & $8.7-14.0$ \\
\hline Tympanum diameter & $7.1( \pm 0.5)$ & $6.4-8.1$ & $7.3( \pm 0.7)$ & $6.2-8.4$ \\
\hline Eye diameter & $10.9( \pm 0.8)$ & $8.9-12.1$ & $10.7( \pm 1.2)$ & $8.8-12.7$ \\
\hline Eye to nostril distance & $5.0( \pm 0.9)$ & $3.6-6.7$ & $5.2( \pm 1.0)$ & $3.5-7.3$ \\
\hline Interocular distance & $12.6( \pm 0.9)$ & $11.4-14.2$ & $12.8( \pm 0.9)$ & $11.2-14.1$ \\
\hline Interorbital distance & $10.6( \pm 0.8)$ & $8.0-12.6$ & $10.8( \pm 0.8)$ & $8.9-12.7$ \\
\hline Inter-nostril distance & $6.7( \pm 0.7)$ & $5.6-7.5$ & $6.9( \pm 0.9)$ & $5.5-8.7$ \\
\hline Snout to nostril distance & $3.6( \pm 0.6)$ & $2.4-4.8$ & $3.8( \pm 0.5)$ & $3.1-4.7$ \\
\hline Hand length & $20.9( \pm 4.7)$ & $1.6-24.0$ & $21.6( \pm 2.1)$ & $17.5-24.8$ \\
\hline Forearm length & $21.5( \pm 2.5)$ & $16.3-25.3$ & $21.9( \pm 3.2)$ & $15.7-26.1$ \\
\hline Upper arm length & $15.3( \pm 1.8)$ & $12.6-19.1$ & $14.1( \pm 2.0)$ & $10.2-17.6$ \\
\hline Tibia length & $21.5( \pm 2.2)$ & $30.6-37.9$ & $21.9( \pm 2.5)$ & $30.0-38.3$ \\
\hline Thigh length & $39.3( \pm 3.6)$ & $29.0-44.7$ & $39.8( \pm 4.0)$ & $32.1-46.0$ \\
\hline Tarsus length & $19.5( \pm 2.5)$ & $12.1-23.4$ & $20.4( \pm 2.1)$ & $16.0-23.5$ \\
\hline Foot length & $34.6( \pm 3.0)$ & $29.5-40.9$ & $34.8( \pm 3.7)$ & $26.5-39.4$ \\
\hline
\end{tabular}

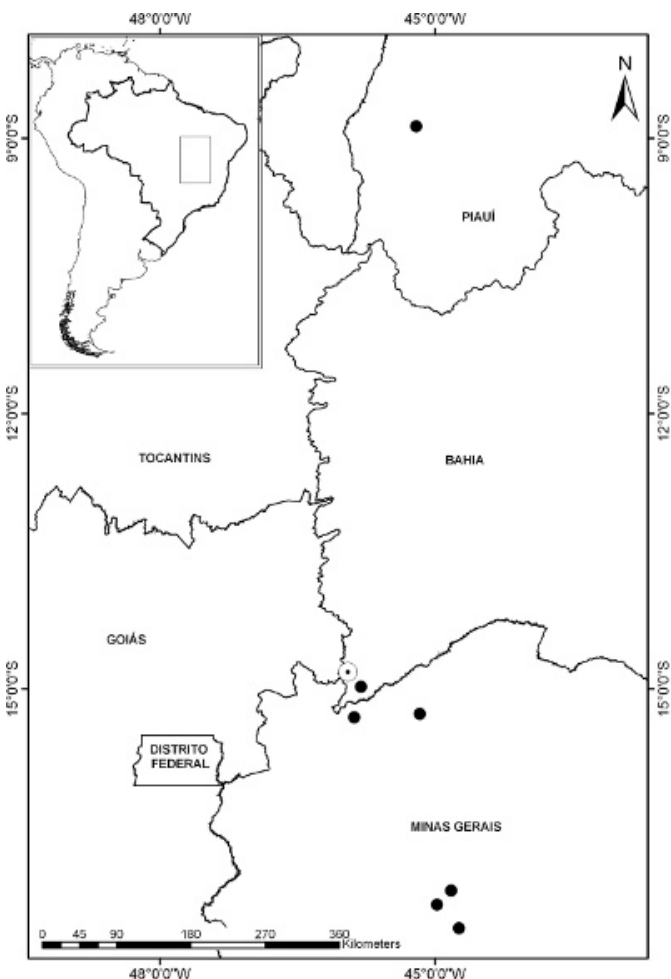

FIG. 4. Distribution of Chaunus veredas. The inset map shows the Central region of Brazil. The dotcenter circle represents the type locality for the species. Map by Ana Paula Medeiros.
Chaunus veredas resembles C. arenarum, C. rubescens, and C. achavali in size, weak development of the cranial crests, short fingers, and shape of parotoid gland. According to Cei (1972), C. rubescens is most closely related to $C$. arenarum, a species with a wide distribution, and many regional forms. According to Maneyro et al. (2004) C. achavali also clusters with $C$. arenarum, and $C$. rubescens.

Currently, considering the $C$. marinus species group, only C. schneideri, C. rubescens, and C. jimi are known to occur in the Cerrado biome (Colli et al., 2002; Brandão and Araújo, 2002; Stevaux, 2002). However, the richness of species belonging to the genus Chaunus in Cerrado is underestimated, and more species remain to be described.

Acknowledgments.-We thank M. Bagno (in memoriam), G. Zerbini, J. Brito, R. Matsushita, A. Teixeira Jr., D. Sifuentes, A. Crema, and G. Fajardo for field help. We also thank $T$. Machado and N. dos Santos (Trijunção Farm) for support and the opportunity to work in southwestern Bahia. We thank G. Colli and M. Zatz for the specimens collected in Buritizeiro municipality and the facilities for work at CHUNB. We thank C. Nogueira for loan the species deposited in MZUSP and M. Di Bernardo (in memoriam) for the species deposited in MCP. J. P. Pombal Jr. gave us access to Museu Nacional/UFRJ. We also would like to thank C. A. da Cruz, B. Pimenta, R. Pinto, D. Nascimento, and C. Ferreira for assistance at MNRJ. A. Garda provided some bibliography. L. 
Campos and A. P. Medeiros helped with the figures. We thank W. R. Heyer and R. de Sá for the helpful suggestions in the manuscript and for English improvements. To T. M. Doan (Associate Editor), E. La Marca, and two anonymous reviewers for revising the manuscript. We thank Conselho Nacional de Desenvolvimento Científico e Tecnológico (CNPq process 142324/2004-3) for fellowship to NMM.

\section{Literature Cited}

Brandão, R. A., And A. F. B. Araújo. 2002. A herpetofauna associada às matas de galeria no Distrito Federal. In J. F. Ribeiro, C. E. L. Fonseca, and J. C. Sousa-Silva (eds.), Cerrado: Caracterização e Recuperação de Matas de Galeria, pp. 560-604. Embrapa, Planaltina, Distrito Federal, Brazil.

CeI, J. M. 1972. Bufo of South America. In W. F. Blair (ed.), Evolution in the Genus Bufo, pp. 82-92. University of Texas Press, Austin.

- 1980. The amphibians of Argentina. Monitore Zoologico Italiano, New Series Monografia, Firenze 2:1-609.

Cochran, D. M. 1955. Frogs of Southeastern Brazil. United States National Museum Bulletin 206:1-423.

Colli, G. R., R. P. Bastos, and A. F. B. Araújo. 2002. The character and dynamics of the Cerrado Herpetofauna. In P. S. Marquis and R. J. Oliveira (eds.), The Cerrados of Brazil: Ecology and Natural History of a Neotropical Savanna, pp. 223-241. Columbia University Press, New York.

Duellman, W. E., AND R. Schulte. 1992. Description of a new species of Bufo from northern Peru with comments on phenetic groups of South America toads (Anura: Bufonidae). Copeia 1992:162-72.

Eterovick, P. C., AND I. SAZIMA. 1999. Description of the tadpole of Bufo rufus with notes on aggregative behavior. Journal of Herpetology 33:711-713.

FaIVOVICH, J., AND G. R. CARRIZO. 1997. La identidad de Bufo missionum Berg, 1896 (Anura, Bufonidae). Cuadernos de Herpetologia 11:81-82.

Frost, D., T. Grant, J. Faivovich, R. Bain, A. HaAs, C. B. Haddad, R. O. De Sá, A. Channing, M. Wilkinson, S. C. Donnellan, C. J. Raxworthy, J. A. Campbell, B. L. Blotto, P. Moler, R. C. Drewes, R. A. Nussbaum, J. D. LyNCH, D. M. GReEN, AND W. C. WheELER. 2006. The amphibian tree of life. Bulletin of the American Museum of Natural History 297:1-370.

Gallardo, J. M. 1961. Anfibios anuros de Misiones con la descripcion de una nueva especie de Crossodactylus. Neotropica 7:33-38.

— 1962. A propósito de Bufo variegatus (Günther), sapo del Bosque Húmedo Antartándico, y las otras especies de Bufo neotropicales. Physis 23:93-102.

Graybeal, A., and D. C. Cannatella. 1995. A new taxon of Bufonidae from Peru, with descriptions of two new species and a review of phylogenetic status of supraspecific bufonid taxa. Herpetologica 51:105-131.

Heyer, W. R., A. S. Rand, C. A. G. Cruz, O. L. Peixoto, And C. E. Nelson. 1990. Frogs of Boracéia. Arquivos de Zoologia São Paulo 31:231-410.
Lavilla, E. O. 1992. Tipos portadores de nombre y localidades tipo de anfibios de Argentina. Acta Zoologica Lilloana 42:61-100.

Maneyro, R., and D. Arrieta. 2000. Reporte de variaciones morfológicas en ejemplares de Bufo arenarum Hensel 1867, con comentarios sobre el grupo marinus. Boletín de la Sociedad Zoologica del Uruguay 12:1-13.

Maneyro, R., D. Arrieta, and R. O. De SÁ. 2004. A new toad (Anura: Bufonidae) from Uruguay. Journal of Herpetology 38:161-165.

Martin, R. F. 1972. Evidence from osteology. In W. F. Blair (ed.), Evolution in the Genus Bufo, pp. 37-70. University of Texas Press, Austin.

Pramuk, J. B. 2006. Phylogeny of South American Bufo (Anura: Bufonidae) inferred from combined evidence. Zoological Journal of the Linnean Society 146:407-452.

Slade, R. W., AND C. Moritz. 1998. Phylogeography of Bufo marinus from its natural and introduced ranges. Proceedings of the Royal Society of London B 265:769-777.

Stevaux, M. N. 2002. A new species of Bufo Laurenti (Anura, Bufonidae) from northeastern Brazil. Revista Brasileira de Zoologia 19:235-242.

Tinen, J. A. 1962. Osteological observations on New World Bufo. American Midland Naturalist 67: 57-183.

Accepted: 30 January 2007.

\section{APPEnDix 1 \\ Specimens Examined}

Chaunus achavali: Brazil: Rio Grande do Sul State, Candiota Municipality, MCP 3937-3940, MCP 4374.

Chaunus arenarum: Argentina: Mendoza, MNRJ 14510-14513, MNRJ 34769. Baía Blanca, Buenos Aires, MNRJ 3871. BRAZIL: Rio Grande do Sul State, Rio Grande Municipality, CHUNB 39950-39952, Torres Municipality, MNRJ 725, MNRJ 5846, MNRJ 93519352, MNRJ 1746, MNRJ 9349, MNRJ 9346, MNRJ 9354. Ozório Municipality, MNRJ 38996-38997. “Praia da Cidreira" MNRJ 38976-38978, MNRJ 38982-38987. Paraná State, Ribeirão Claro Municipality, MNRJ 3883.

Chaunus ictericus: Brazil: São Paulo State, Atibaia Municipality, CHUNB 39960, Botucatu Municipality, CHUNB 39961-39966, 39978. Paraná State, Palma Municipality, MNRJ without number. Rio de Janeiro State, Nova Friburgo Municipality, MNRJ 3223232238. Miguel Pereira Municipality, MNRJ 3173931741. Restinga de Maricá, MNRJ 38989-38995. Santa Catarina State, Canoinhas Municipality, MNRJ 1045110452, MNRJ 1975. São Paulo State, Campos do Jordão Municipality, MNRJ 26239. Ribeirão Grande Municipality, MNRJ 28446-28456. Minas Gerais State, Além Paraíba Municipality, MNRJ 3105. Poços de Caldas Municipality, MNRJ 38988. Rio Grande do Sul State, Palmeira das Missões Municipality, MNRJ 3845.

Chaunus jimi: Brazil: Bahia State, Vitória da Conquista Municipality, MNRJ 16168-16170, MNRJ 2625. Juazeiro Municipality, MNRJ 1323. Pernambuco State, Caruaru Municipality, MNRJ 38622-38623. Rio Grande do Norte State, Mossoró Municipality, MNRJ 38588. 
Chaunus marinus: Brazil: Amazonas State, Benjamin Constant Municipality, MNRJ 2575, MNRJ 1183911841. Amapá State, Macapá Municipality, MNRJ 15440, MNRJ 4157. Roraima State, Pacaraima Municipality, MNRJ 38998-39001. Pará State, Óbidos Municipality, MNRJ 20116. Belém Municipality MNRJ 32203. Maranhão State, Pindaré-Mirim Municipality, MNRJ 10367-10371, MNRJ 1930. Venezuela: Zulia State, Lago Maracaibo, MNRJ 37281.

Chaunus schneideri: Brazil: Distrito Federal, Brasília, CHUNB 39975. São Paulo State, CHUNB 39972-39974, 39976. Espírito Santo State, Conceição da Barra Municipality, MNRJ 20950-20951. Bahia State, Barreirinhas Municipality, MNRJ 1319-1321. Mato Grosso do Sul State, Bonito Municipality, MNRJ 39018-39019. Goiás State, Mambaí Municipality, MNRJ 27893. Minas Gerais State, Lagoa Santa Municipality, MNRJ 1339, MNRJ 37003-37004. Belo Horizonte Municipality, AL 253-254 (paratypes of Chaunus paracnemis). Pernambuco State, Dormentes Municipality, MNRJ 30022-30023. PARAGUAY: NHMB 1916 (holotype of C. schneideri).
Chaunus sp. Brazil: Rio Grande do Norte State, Mossoró Municipality, MNRJ 38597.

Chaunus rubescens: Brazil: Distrito Federal, Brasília, CHUNB 39969-39960. Minas Gerais State, Belo Horizonte Municipality, AL 993 (paratype of Chaunus rufus). Presidente Olegário Municipality, MNRJ 34766, MNRJ 22470. Pirapora Municipality, AL 2414. João Pinheiro Municipality, MNRJ 3884-3845. Lagoa Santa Municipality MNRJ 1409.

Chaunus veredas: Brazil: Bahia State, Cocos Municipality CHUNB 40282, CHUNB 37437-37438, CHUNB 38652-38654, Minas Gerais State, Grande Sertão Veredas National Park, Chapada Gaúcha Municipality, MZUSP 128285A-128293A, Serra das Araras State Park, Serra da Araras Municipality, CHUNB 3410634109, 34112-34114, Buritizeiro Municipality, CHUNB 43327-43333, Pirapora Municipality, MNRJ 1387, MNRJ 39014-39017, MNRJ 39051-39052, Corrente Farm, Várzea da Palma Municipality, MNRJ 39035, Piauí State, Estação Ecológica Uruçuí-Una, UruçuíUna Municipality, MNRJ 39050. 